\title{
Legacy effects of soil fertility management on cereal dry matter and nitrogen grain yield of organic arable cropping systems
}

\author{
Johannes Wilhelmus Maria Pullens ${ }^{\mathrm{a}, *}$, Peter Sørensen ${ }^{\mathrm{a}}$, Bo Melander ${ }^{\mathrm{b}}$, Jørgen Eivind Olesen ${ }^{\mathrm{a}}$ \\ ${ }^{a}$ Aarhus University, Department of Agroecology, Blichers Allé 20, P.O. Box 50, 8830, Tjele, Denmark \\ ${ }^{\mathrm{b}}$ Aarhus University, Department of Agroecology, Forsogsvej 1, 4200, Slagelse, Denmark
}

\section{A R T I C L E I N F O}

\section{Keywords:}

organic agriculture

soil fertility

yield

cropping cycles

\begin{abstract}
A B S T R A C T
The yields of crops in organic farming are typically lower than in conventional farming, although this depend greatly on local climatic conditions and on crop and soil management. A long-term study over three consecutive 4-year cropping cycles at three locations in Denmark compared organic arable cropping systems varying in fertilization management (green manure crops, cover crops, livestock manure) to study the long-term effects of soil fertility management on crop yields. The analysis of the results showed that the nitrogen $(\mathrm{N})$ derived from cover crops has a legacy effect on the dry matter and $\mathrm{N}$ grain yield of spring barley being traceable 5-8 years back in time. The net $\mathrm{N}$ input of crop residues and manure for the crop cycles 1-4 and 5-8 years prior to the winter wheat had a significant effect on both the dry matter and $\mathrm{N}$ grain yield of wheat.

The management of organic cropping systems should focus on reducing the weed pressure, promoting soil fertility and increasing the soil $\mathrm{N}$ supply to optimize crop yields. For both winter wheat and spring barley, the weed pressure reduced both crop dry matter and the $\mathrm{N}$ grain yield. A cover crop as pre-crop had a significant positive effect on both dry matter and $\mathrm{N}$ yield of spring barley, while a cover crop in the rotation did not significantly affect grain yield of winter wheat. For both winter wheat and spring barley, manure application was most effective in increasing crop yields. However, $\mathrm{N}$ in applied crop residues also had considerable yieldenhancing effects. For winter wheat, the $\mathrm{N}$ inputs from crop residues from previous crop rotation cycles (1-4 and 5-8 years) significantly increased yields, while for spring barley, $\mathrm{N}$ input in crop residues from incorporated cover crop and the long-term crop rotation cycle (5-8 years) significantly enhanced both dry matter and $\mathrm{N}$ grain yield. These legacy effects of soil fertility management through enhancing and retaining organic $\mathrm{N}$ inputs of organic arable cropping suggest that a holistic approach to soil and crop management is necessary, and this needs to focus on increasing weed suppression, soil fertility and targeting manure inputs for enhanced $\mathrm{N}$ uptake.
\end{abstract}

\section{Introduction}

Modern agricultural systems exert significant pressures on the environment, biodiversity and climate, e.g. via nutrient pollution of aquatic ecosystems, land-use changes and greenhouse gas emissions (Willett et al., 2019), and with a growing population and an increasing demand for food, this pressure will become greater (Godfray et al., 2010; Willett et al., 2019). These challenges can only be overcome through a combined effort that involves dietary changes, reduction of food waste, and improved productivity of agricultural systems through improved technologies and management (Springmann et al., 2018).

Organic farming is considered a way to reduce the pressure on the environment due to bans on the use of synthetic fertilizers, herbicides, fungicides and insecticides. In organic farming these chemical inputs are replaced with natural cycles, the use of manure and compost for fertilization and mechanical means for weed control to increase the biodiversity and potentially improving the soil quality (Mäder et al., 2002). However, the change of management from conventional to organic farming will result in lower yields (on average 19\%) compared to conventional farming (Knapp and van der Heijden, 2018). These yield gaps are even greater in arable systems in temperate climatic conditions with values of 30-40\% (Cadillo-Benalcazar et al., 2020; De Ponti et al., 2012; Gabriel et al., 2013; Ponisio et al., 2015; Seufert et al., 2012; Shah et al., 2017). There are many causes of the yield gap between high-input conventional systems and organic farming; such as higher disease and pest incidence in organic farming (Knapp and van der Heijden, 2018;

\footnotetext{
* Corresponding author.

E-mail address: jwmp@agro.au.dk (J.W.M. Pullens).
} 
Shah et al., 2017), the occurrence of weeds (Melander et al., 2016) and a lower input of fertilizers causing nutrient deficiencies (Olesen et al., 2009, 2007). The yield gap is particularly large in countries, such as Denmark, where the actual yields in conventional agriculture are close to the genetic yield potential (De Ponti et al., 2012; Schils et al., 2018).

Denmark has experienced a considerable increase in farm area used for organic farming (Statistics Denmark, 2019), which is projected to further increase. This expansion is partly conditioned on an increase in arable crop production, which requires higher and more stable crop yields to make production profitable and to provide the required quantities and qualities for food and feed consumption (Cadillo-Benalcazar et al., 2020; De Ponti et al., 2012; Gabriel et al., 2013; ICROFS, 2019). Over the past two decades, there has been little, if any, increase in achieved yields of arable crops in Danish organic farming (Statistics Denmark, 2019).

Many studies point to limiting nutrient availability, in particular the limited nitrogen $(\mathrm{N})$ supply, and weed pressure as being the primary reasons for low yields in organic arable farming (Knapp and van der Heijden, 2018; Olesen et al., 2009, 2007). The mineral $\mathrm{N}$ available for crops in organic farming originate partly from applied $\mathrm{N}$ in organic fertilizers (e.g. manures and composts) and partly from mineralization of $\mathrm{N}$ in soil organic matter and incorporated crop residues. These deficiencies occur due to low $\mathrm{N}$ input rates in organic farming and due $\mathrm{N}$ losses, in particular from nitrate leaching (De Notaris et al., 2018). These losses can be mitigated and the $\mathrm{N}$ retained in the soil system by growing cover crops, which reduce nitrate leaching by taking up soil mineral $\mathrm{N}$ during the period when no cash crop is being grown (Zhao et al., 2020). The use of legume-based cover crops further adds $\mathrm{N}$ to the system via BNF (De Notaris et al., 2018; Pandey et al., 2018, 2017). Apart from dairy farms and other livestock intensive production systems, livestock manure supply is limited in organic cropping systems (Berry et al., 2006). Therefore, much of the plant $\mathrm{N}$ uptake is obtained from mineralization of plant residues and soil organic matter. This makes the accounting of such sources and inputs of particular importance for designing plant nutritional management schemes in organic farming (Petersen et al., 2013). This involves both the application of N-rich amendments as well as the design of crop rotations. The use of legumes that can fix $\mathrm{N}$ through biological nitrogen fixation (BNF) should thus be considered of higher importance than present to replenish the $\mathrm{N}$ stock for future crops.

Crop rotation is fundamental in ensuring efficient use of $\mathrm{N}$ in organic farming, and it contains alternate phases of building up and exploiting soil N. The composition of crop rotations also affects weed abundance, in particular perennial weeds, where for example crop sequences with legumes, cereal-legume mixtures and cover crops can result in severe infestations with Elytrigia repens (Rasmussen et al., 2014) or Cirsium arvense (Melander et al., 2016). The balance between fertility building and exploitation is critical for maintaining production and soil fertility as well as minimizing losses. In the building phase, legumes add $\mathrm{N}$ to the system through BNF, which later becomes available to the following crops through mineralization of above- and below-ground plant residues. Crop rotations often contain cover crops that aim to retain $\mathrm{N}$ that would otherwise have been lost by leaching, and which adds to the $\mathrm{N}$ supply for the following crop by microbial turnover in the soil of the $\mathrm{N}$ captured in the cover crop.

The challenges related to designing crop rotations and fertility management schemes that aim to increase crop yields by improved $\mathrm{N}$ supply relies on both estimating the $\mathrm{N}$ fertility building through inputs in plant residues and the timing of $\mathrm{N}$ release for the following crops. Such information may be obtained through the use of crop simulation models (Doltra et al., 2019); however, organic cropping systems are complex and difficult to model. There is, therefore, need to support this modelling by empirical analyses of the crop $\mathrm{N}$ supply achieved through the rotational components of cropping systems. So far, most experimental studies in organic farming have focused on short-term $\mathrm{N}$ dynamics or restricted analyses to one single rotational cycle, pointing to the need for evidence drawn from long-term experiments (Knapp and van der Heijden, 2018).

The study of long-term effects of fertility building measures in organic farming on crop yields demands an experimental setup that is very scarcely available. It requires that the studied measures have been implemented over a long period of time in well-managed field experiment with good records of the amount of $\mathrm{N}$ inputs in manure and crop residues. Here, we used a 13-year dataset from a unique long-term field experiment on arable organic farming carried out at three sites in Denmark. This dataset provides a holistic crop rotation perspective with the possibility to study legacy effects of previous cycles of the crop rotations. These effects may entail the effects of crop residues, manure application, cover crops, weed percentage and soil $\mathrm{N}$ on the dry matter (DM) and $\mathrm{N}$ yield of cereal crops (spring barley and winter wheat) within the current rotation cycle (1-4 year) and of the previous two rotation cycles (previous 8 years). This offers a unique opportunity to study the long-term legacy effects of soil fertility management on cereal grain yield in organic arable farming.

The main objectives of this study are i) to assess a potential legacy effects of cover crops on cereal yield, ii) to assess differences between short-term and long-term effects of the incorporation of plant residues, manure and cover crops on cereal yield, iii) to assess the effects of legumes on crop yields in a crop rotation, and iv) to analyse the legacy effects of organic farming management practices over three crop rotation cycles on three different soil types in Denmark.

\section{Materials and Methods}

\subsection{Long term experiment}

A long-term cropping system experiment was carried out in Denmark during 1997-2009 including three consecutive crop rotation cycles (1997-2000, 2001-2004, and 2005-2009) to compare different organic arable cropping systems with different cereal-based crop rotations (Table 1) at three sites representing different soils and climatic conditions (Olesen et al., 2000). Jyndevad has a coarse sandy soil (Orthic Haplohumod) with a low content of soil organic matter (2.0\%) at start of the experiment in an area of high rainfall (mean annual precipitation (MAP): $964 \mathrm{~mm}$, Table 2). Foulum has a loamy sand soil (Typic Hapludult) and moderate content of soil organic matter (3.8\%) with moderate rainfall (MAP: $704 \mathrm{~mm}$, Table 2). Flakkebjerg has a sandy loam soil (Typic Agrudalf) and a low content of soil organic matter (1.7\%) with low rainfall (MAP: $626 \mathrm{~mm}$, Table 2). The year prior to commencing this long-term experiment (1996), spring barley under-sown with grass-clover was grown at all locations. No pesticides were applied since 1996, but prior to 1996, all locations were under conventional cropping practices (Rasmussen et al., 2006). A detailed description of the sites and soil conditions is given by Djurhuus and Olesen (2000) and Olesen et al. (2000).

\subsection{Experimental design}

The experiment used 4-year crop rotations in the $1^{\text {st }}$ and $2^{\text {nd }}$ cycle, an interim/transition year (2005) and 4-year crop rotations in the $3^{\text {rd }}$ cycle with all crops in the rotations being represented every year in the field plots. This resulted in 64 plots at each site (until 2004: 2 rotation treatments $\times 2$ cover crop treatments $(+\mathrm{CC} /-\mathrm{CC}) \times 2$ manure treatments $(+\mathrm{M} /-\mathrm{M}) \times 4$ crops $\times 2$ replicates). The plot sizes were 378,216 and 169 $\mathrm{m}^{2}$ at Jyndevad, Foulum and Flakkebjerg, respectively. In the $1^{\text {st }}$ and $2^{\text {nd }}$ cycles, three 4-year crop rotations (O1, O2 and O4) managed with organic farming were compared (Table 1). A whole year grass-clover green manure was included in crop rotations $\mathrm{O} 1$ and $\mathrm{O} 2$, but not in O4. Crop rotation $\mathrm{O} 2$ was included at all three locations throughout the experiment. Grain legume crops were included in $\mathrm{O} 4$ instead of grassclover. The crop rotations $\mathrm{O} 1$ and $\mathrm{O} 2$ were tested at Jyndevad, and $\mathrm{O} 2$ and $\mathrm{O} 4$ were tested at Foulum and Flakkebjerg. Initially, the sandy soil 
Table 1

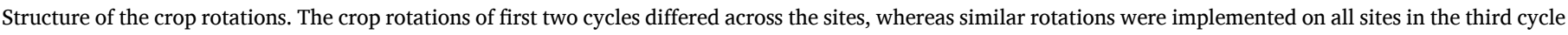
(JY: Jyndevad, FO: Foulum and FL: Flakkebjerg).

\begin{tabular}{|c|c|c|c|c|c|c|c|c|c|c|}
\hline $\begin{array}{l}\text { Crop rotations } \\
\text { Cycles }\end{array}$ & Field & $\begin{array}{l}\text { O1 } \\
\text { Crop }\end{array}$ & $\mathbf{M}^{1}$ & $\mathrm{CC}^{2}$ & $\begin{array}{l}\mathrm{O} 2 \\
\text { Crop }\end{array}$ & $\mathbf{M}^{1}$ & $\mathrm{CC}^{2}$ & $\begin{array}{l}\text { O4 } \\
\text { Crop }\end{array}$ & $\mathbf{M}^{1}$ & $\mathrm{CC}^{2}$ \\
\hline $1^{\text {st }}$ cycle & 1 & S. barley:ley & 50 & & S. barley:ley & 50 & & S. oat & 40 & $+^{5}$ \\
\hline \multirow[t]{3}{*}{$1997-2000$} & 2 & Grass-clover & 0 & & Grass-clover & 0 & & W. wheat & 70 & $+^{5}$ \\
\hline & 3 & S. wheat & 50 & $+^{3}$ & W. wheat & 50 & $+^{3}$ & W. cereal $^{6}$ & 70 & $+^{5}$ \\
\hline & 4 & Lupin & 0 & $+{ }^{4}$ & Pea - barley & 0 & $+^{4}$ & Pea - barley & 0 & $+^{4}$ \\
\hline $2^{\text {nd }}$ cycle & 1 & S. barley:ley & 50 & & S. barley:ley & 50 & & W. wheat & 50 & $+^{4}$ \\
\hline \multirow[t]{3}{*}{ 2001-2004 } & 2 & Grass-clover & 0 & & Grass-clover & 0 & & S. oat & 50 & $+^{4}$ \\
\hline & 3 & S. oat & 30 & $++^{3}$ & W. cereal $^{7}$ & 50 & $+^{3}$ & S. barley & 50 & $+^{3}$ \\
\hline & 4 & Pea - barley & 0 & $+^{4}$ & Lupin & 0 & $+^{4}$ & Lupin & 0 & \\
\hline Locations & & JY & & & JY, FO, FL & & & FO, FL & & \\
\hline $3^{\text {rd }}$ cycle & 1 & Discontinued & & & S. barley/ley & 60 & & S. barley & 60 & $+^{4}$ \\
\hline \multirow[t]{3}{*}{ 2005-2009 } & 2 & & & & Grass-clover & 0 & & F. bean & 0 & $+^{4}$ \\
\hline & 3 & & & & Potato & 110 & & Potato & 110 & \\
\hline & 4 & & & & W. wheat & 110 & $+^{4}$ & W. wheat & 110 & $+{ }^{4}$ \\
\hline Locations & & & & & JY, FO, FL & & & JY, FO, FL & & \\
\hline
\end{tabular}

${ }^{1}$ M: Manure-N application target rates in $+\mathrm{M}$ treatments. Unit: $\mathrm{kg} \mathrm{NH}_{4}-\mathrm{N} \mathrm{ha}^{-1} \mathrm{yr}^{-1}$ in $1^{\text {st }}$ and 2 cycles and $\mathrm{kg}$ total-N ha ${ }^{-1} \mathrm{yr}^{-1}$ in the $3^{\text {rd }}$ cycle.

2 CC: Crops succeeded by cover crops in + CC treatments.

3 Monocultures or mixtures of non- $\mathrm{N}_{2}$-fixing cover crop.

${ }^{4}$ Mixtures of $\mathrm{N}_{2}$-fixing and non- $\mathrm{N}_{2}$-fixing cover crop.

5 White clover.

6 Winter triticale at Foulum, winter wheat at Flakkebjerg.

7 Winter rye at Jyndevad, otherwise winter wheat.

Table 2

The mean annual temperature $(\mathrm{C})$ and precipitation $(\mathrm{mm})$ during the main growing season (April to July) of each cycle.

\begin{tabular}{|c|c|c|c|c|c|c|}
\hline & \multicolumn{2}{|l|}{ Jyndevad } & \multicolumn{2}{|l|}{ Foulum } & \multicolumn{2}{|l|}{ Flakkebjerg } \\
\hline & Temperature & Precipitation & Temperature & Precipitation & Temperature & Precipitation \\
\hline \multicolumn{7}{|l|}{$1^{\text {st }}$ cycle } \\
\hline 1997 & 12.2 & 302 & 11.4 & 284 & 11.9 & 163 \\
\hline 1998 & 12.5 & 343 & 11.3 & 228 & 12.1 & 231 \\
\hline 1999 & 12.8 & 267 & 11.8 & 261 & 12.5 & 254 \\
\hline 2000 & 12.8 & 260 & 11.9 & 188 & 12.7 & 138 \\
\hline $\begin{array}{l}\text { Mean } \\
2^{\text {nd }} \text { cycle }\end{array}$ & 12.6 & 293 & 11.6 & 240 & 12.3 & 197 \\
\hline 2001 & 12.3 & 219 & 11.3 & 189 & 12.5 & 163 \\
\hline 2002 & 13.6 & 356 & 12.6 & 241 & 13.6 & 229 \\
\hline 2003 & 13.5 & 279 & 12.6 & 275 & 13.2 & 248 \\
\hline 2004 & 12.3 & 254 & 11.4 & 235 & 11.7 & 250 \\
\hline Mean & 12.9 & 277 & 12.0 & 235 & 12.7 & 223 \\
\hline \multicolumn{7}{|c|}{ Interim year } \\
\hline $\begin{array}{l}2005 \\
3^{\text {rd }} \text { cycle }\end{array}$ & 12.9 & 288 & 11.9 & 212 & 12.3 & 156 \\
\hline 2006 & 13.6 & 183 & 12.6 & 197 & 13.2 & 185 \\
\hline 2007 & 13.3 & 375 & 12.6 & 226 & 13.5 & 302 \\
\hline 2008 & 13.2 & 144 & 12.7 & 148 & 13.3 & 131 \\
\hline 2009 & 13.4 & 291 & 12.5 & 208 & 13.3 & 184 \\
\hline Mean & 13.3 & 256 & 12.5 & 198 & 13.1 & 192 \\
\hline
\end{tabular}

at Jyndevad had been considered unsuitable for rotation systems without grass-clover green manure, and therefore both rotations $(\mathrm{O} 1$ and $\mathrm{O} 2)$ in the first two cycles contained grass-clover. In the $3^{\text {rd }}$ cycle, $\mathrm{O} 1$ was converted to $\mathrm{O} 4$ at Jyndevad, but the other treatment combinations in this rotation were maintained. In the third cycle, only three treatment combinations of cover crop and manure was continued $(+\mathrm{M}$ / $-\mathrm{CC},+\mathrm{M} /+\mathrm{CC},-\mathrm{M} /+\mathrm{CC}$ ), whereas the treatment combination $-\mathrm{M} /-\mathrm{CC}$ was converted to a conventional crop rotation that is not used in this study. Therefore, only 48 plots per location were available in the third cycle.

The crops used in the different rotations, the distribution of manure application, legume and non-legume cover crops for each crop rotation and cycle are presented in Table 1 . The crops included spring barley (Hordeum vulgare L.), spring and winter wheat (Triticum aestivum L.), winter rye (Secale cereale L.), winter triticale (x Triticosecale), lupin (Lupinus angustifolius L.), faba bean (Vicia faba L.), a mixture of pea (Pisum sativum L.) and spring barley, spring oat (Avena sativa), potato
(Solanum tuberosum L.) and grass-clover, that included perennial ryegrass (Lolium perenne L.), white clover (Trifolium repens L.) and red clover (Trifolium pratense L.). The non-legume cover crops varied between monocultures of perennial ryegrass or mixtures of perennial ryegrass and chicory (Cichorium intybus L.) undersown in spring. The legume-based cover crops varied between pure stands of white clover, mixtures of ryegrass and white clover or mixtures of ryegrass and white clover and red clover or mixtures of ryegrass, black medic (Medicago lupulina L.), serradella (Ornithopus sativus Brot.), birdsfoot trefoil (Lotus corniculatus L.) and subterranean clover (Trifolium subterraneum L.) or a mixture of ryegrass and chicory and black medic and kidney vetch (Anthyllis vulneraria L.). All these cover crop mixtures were undersown in cereal or grain legume crops in spring. Apart from the $3^{\text {rd }}$ rotation at Flakkebjerg where a mixture of winter rye and hairy vetch (Vicia villosa L.) and fodder radish (Raphanus sativus oleiformis L.) was sown after harvest of the main crop to allow for mechanical control of the highly abundant perennial weeds. The seed rates of the cover crops were 
typically about $10 \mathrm{~kg} \mathrm{ha}^{-1}$ for undersown cover crops with the legume component constituting less than $50 \%$. The seed rates for autumn-sown cover crops was slightly higher, since this involved species with larger seeds.

Mouldboard ploughing prior to spring-sown crops was normally done in spring at Jyndevad and Foulum and in November at Flakkebjerg. The grass-clover was spring-ploughed in 01 , followed by spring wheat, and autumn-ploughed in $\mathrm{O} 2$, followed by winter wheat in the $1^{\text {st }}$ and $2^{\text {nd }}$ cycle. In the $3^{\text {rd }}$ cycle, grass-clover was spring-ploughed prior to potato.

During the $1^{\text {st }}$ and $2^{\text {nd }}$ cycle $40 \%$ of the $\mathrm{N}$ demand of the specific rotation was applied as livestock manure (slurry) to the plots $(+M)$, with $\mathrm{N}$ demand defined according to Danish national standards for conventional crops (Plantedirektoratet, 1997). The manure application rates in the $3^{\text {rd }}$ cycle were changed according to a revised Danish national organic farming standard, that allowed import of animal manure of conventional origin corresponding to $70 \mathrm{~kg}$ total- $\mathrm{N} \mathrm{ha}^{-1} \mathrm{yr}^{-1}$ at rotation level (Plantedirektoratet, 2005) (Table 1). No manure was applied to $\mathrm{N}$ fixing crops (Table 1 ). The actual manure $\mathrm{N}$ rates varied slightly between locations due to the type of manure being used. During the $1^{\text {st }}$ and $2^{\text {nd }}$ cycle, cattle slurry was used at Jyndevad, mixed cattle and pig slurry at Foulum and anaerobically digested slurry at Flakkebjerg (Askegaard et al., 2011). In the $3^{\text {rd }}$ cycle, only pig slurry or anaerobically digested pig slurry was used at all locations.

The slurry was injected to 8-10 $\mathrm{cm}$ depth for spring cereals and potato, whereas surface application with trail hoses was used for winter cereals (Brozyna et al., 2013). In the $1^{\text {st }}$ and $2^{\text {nd }}$ cycle, the grass-clover was solely used as a green manure crop, where the cuttings were left on the soil. In the $3^{\text {rd }}$ cycle, the cuttings were removed in the $02 /+\mathrm{M}$ treatments, while they were left on the soil in the $\mathrm{O} 2 /-\mathrm{M}$ treatments. This latter simulates the removal of grass-clover cuttings for biogas production and the use of the biogas residue (slurry) as manure in the system (Brozyna et al., 2013; Knudsen et al., 2014). The straw of the cereals was finely chopped and left on the field in all treatments.

\subsection{Irrigation}

At Jyndevad, irrigation was applied according to the need of the individual crops in all cycles. After the establishment of potato in the $3^{\text {rd }}$ cycle, irrigation was used in the plots with potato at Flakkebjerg. At Foulum all crops in the $3^{\text {rd }}$ cycle were irrigated at the same rate following the irrigation demand of potato (Shah et al., 2017).

\subsection{Weed control}

Weed harrowing in spring was applied one to three times in the cash crops to control annual weeds. Grass-clover crops were generally cut three times per growing season in May, July and at the end of August, which suppressed C. arvense (Melander et al., 2016). Potato ridges in the third cycle were cultivated once or twice close to crop emergence using a rotary cultivator to build up the ridges and to control annual weeds and E. repens. Plots infested with perennial weeds were cultivated with a stubble cultivator post-harvest in the -CC treatments. In the first two cycles, perennial weeds were not controlled in the $+\mathrm{CC}$ treatments. Late sowing, tall winter wheat crop varieties (Rasmussen et al., 2006) and $5-50 \%$ higher seed rates than recommended were applied (Weiner et al., 2001) to suppress weed growth (Rasmussen and Rasmussen, 2000). Due to increasing problems with perennial weeds in the $3^{\text {rd }}$ cycle at the Flakkebjerg site, stubble cultivations were made post-harvest also in the + CC treatments prior to establishing the cover crops.

\subsection{Harvesting and measurements}

Grain yields were measured at maturity in two subplots in each plot using a combine harvester. The size of harvested plots was $45 \mathrm{~m}^{2}$ for Jyndevad, $48 \mathrm{~m}^{2}$ for Foulum and $32 \mathrm{~m}^{2}$ for Flakkebjerg (Olesen et al., 2009). To determine total crop production, samples of total aboveground biomass were taken in two $0.5 \mathrm{~m}^{2}$ sample areas in each plot at GS 85, 1-2 weeks prior to crop harvest maturity in the winter cereals. Samples of total aboveground biomass in the grass-clover were taken in two $0.5 \mathrm{~m}^{2}$ sample areas in each plot at each cut. Samples of aboveground biomass of cover crop and weeds were taken around 1 November in two $0.5 \mathrm{~m}^{2}$ plots. The total DM content of the grains, seed and tubers, and of the aboveground biomass samples was measured after oven drying the plant material at $80{ }^{\circ} \mathrm{C}$ for $24 \mathrm{~h}$. The total $\mathrm{N}$ was determined on finely milled samples from each plot by the Dumas method (Hansen, 1989). From 2005, total $\mathrm{N}$ in cereal grains was determined by near-infrared spectroscopy (InfratecTM 1241 Grain Analyzer, Foss A/S; Büchmann et al. (2001). To determine the amount of $\mathrm{N}$ in crop residues, the harvested $\mathrm{N}$ in grain yield or grass-clover was subtracted from the measured total aboveground biomass $\mathrm{N}$.

To determine weed pressure, samples of total aboveground biomass were taken in 3-4 sub-plots of $0.25 \mathrm{~m}^{2}$ sample areas in each plot at GS59 in the winter cereals according to the BBCH scale (Lancashire et al., 1991). These samples were separated into cereal, cover crop and weeds for assessing weed pressure. Samples of total aboveground biomass in the grass-clover were taken in two $0.5 \mathrm{~m}^{2}$ sample areas in each plot at each cut. Samples of aboveground biomass of cover crop and weeds were taken around 1 November in two $0.5 \mathrm{~m}^{2}$ plots.

The total DM content of the grains, seed and tubers, and of the aboveground plant biomass samples was measured after oven drying the plant material at $80{ }^{\circ} \mathrm{C}$ for $24 \mathrm{~h}$. The total $\mathrm{N}$ was determined on finely milled samples from each plot by the Dumas method (Hansen, 1989). From 2005, total $\mathrm{N}$ in cereal grains was determined by near-infrared spectroscopy (InfratecTM 1241 Grain Analyzer, Foss A/S; Büchmann et al. (2001).

\subsection{Statistical analyses}

In this study, we focus on the DM and $\mathrm{N}$ yield of winter wheat and spring barley from all sites and in all crop rotations. All data were analysed in the $\mathrm{R}$ environment, using version 3.5.0 ( $\mathrm{R}$ Development Core Team. R Foundation for Statistical Computing, 2018). Analyses were done for yield data from all years with a linear mixed-effect model separately for each site to investigate the effects of the rotation on the $\mathrm{DM}$ and $\mathrm{N}$ yield ( $\mathrm{kg} \mathrm{DM} \mathrm{ha}{ }^{-1}, \mathrm{~kg} \mathrm{~N} \mathrm{ha}^{-1}$ ) with years as random effect (lmer from the lme4 package (Bates et al., 2015)), following:

Winter wheat:

$D M$ or $N$ yield $=$ manure $+G C+G C R+C C+$ Weedpct

Spring barley:

$D M$ or $N$ yield $=$ manure $+G C R+C C+$ Weedpct

where manure is the amount of ammonium-N in manure $\left(\mathrm{kg} \mathrm{N} \mathrm{ha}^{-1}\right), G C$ is the presence of grass-clover as a pre-crop (factor), GCR is the presence of grass-clover in the rotation (factor), $C C$ is the presence of cover crop in rotation (factor), and Weedpct is the weed biomass (\% of total DM biomass).

A linear model with fixed intercept through the origin was used to investigate the effects of $\mathrm{N}$ inputs on yield in the third cycle (20062009), using $\operatorname{lm}($ ) from the stats package (R Development Core Team. $R$ Foundation for Statistical Computing, 2018)) for the regression analysis without random effects. The $\mathrm{N}$ inputs investigated were 1) total $\mathrm{N}$ in the top $25 \mathrm{~cm}$ of the soil at the start of the experiment (1997), 2) annual organic $\mathrm{N}$ inputs as crop residues and manure to the soil since the start of the experiment (divided into previous cycles, 1-4, 5-8 years prior to the harvest year), 3) total $\mathrm{N}$ incorporated in spring in grass-clover or cover crops in the harvest year, 4) ammonium- $\mathrm{N}$ in the manure applied to the crop in the harvest year, and 5) the percentage of weed biomass in the crop at anthesis in the harvest year:

Winter wheat: 
DM or $N$ yield $=$ SoilN + NinputP + NorgMan + manure $*$ site + Weedpct

Spring barley:

$D M$ or $N$ yield $=$ SoilN + NinputP + NorgMan $+N C C+$ manure $*$ site

$$
+ \text { Weedpct }
$$

where SoilN is the amount of $\mathrm{N}$ in the top $25 \mathrm{~cm}$ of the soil $\left(\mathrm{kg} \mathrm{N} \mathrm{ha}^{-1}\right)$, NinputP is the average amount of $\mathrm{N}$ returned in aboveground plant residues in previous cycles (1-4 and 5-8 years, $\mathrm{kg} \mathrm{N} \mathrm{ha}^{-1} \mathrm{yr}^{-1}$ ), NOrgMan is the average amount of organic $\mathrm{N}$ in manure applied in previous cycles (1-4 and 5-8 years, $\mathrm{kg} \mathrm{N} \mathrm{ha}^{-1} \mathrm{yr}^{-1}$ ), NCC the amount of $\mathrm{N}$ in aboveground cover crops prior to the actual crop $\left(\mathrm{kg} \mathrm{N} \mathrm{ha}^{-1}\right)$, manure is the amount of ammonium in manure applied to the crop $\left(\mathrm{kg} \mathrm{N} \mathrm{ha}^{-1}\right)$, and Weedpct is the weed biomass ( $\%$ of total biomass). For the regression analysis of crop DM yield, the model is not forced through the origin, since no 1:1 relation is expected between the available $\mathrm{N}$ and $\mathrm{N}$ applied and DM yield. The effect of $\mathrm{N}$ in crop residues and manure are split between the effect of applications $1-4$ and 5-8 years prior to the actual crop (NinputP4, NinputP8, NOrgMan4 and NOrgMan8) to quantify the extent of legacy effects. Manure is highly correlated with the amount of manure $\mathrm{N}$ applied 1-4 and 5-8 years ago (NOrgMan4 and NOrgMan8, Figs. 1 and 2); thus, the legacy effect (NOrgMan4 and NOrgMan8) of the manure was removed from the further analysis, and instead an analysis was performed where the organic $\mathrm{N}$ in manure was added to the $\mathrm{N}$ in crop residues for both previous periods (1-4 and 5-8 years).

\section{Results}

\subsection{Crop yields and weed infestation}

The yield of winter wheat across all cycles at all three locations varied greatly (Table 3), ranging from 120 to $6905 \mathrm{~kg} \mathrm{DM} \mathrm{ha}^{-1}$. The lowest winter wheat yields (DM and N) was found at Jyndevad (Table 3), and this location also showed the highest percentage of weed in the biomass. The highest yield was recorded for Foulum, where on average the lowest amount of weed biomass was recorded. The patterns differed for the yields of spring barley, where the DM yield ranges between 1751 to $6319 \mathrm{~kg} \mathrm{ha}^{-1}$. The greatest DM yield was recorded at Jyndevad with $6319 \mathrm{~kg} \mathrm{ha}^{-1}$, while Foulum had the greatest overall average DM yield with $4505 \mathrm{~kg} \mathrm{ha}^{-1}$. The lowest average DM yield and $\mathrm{N}$ yield of spring

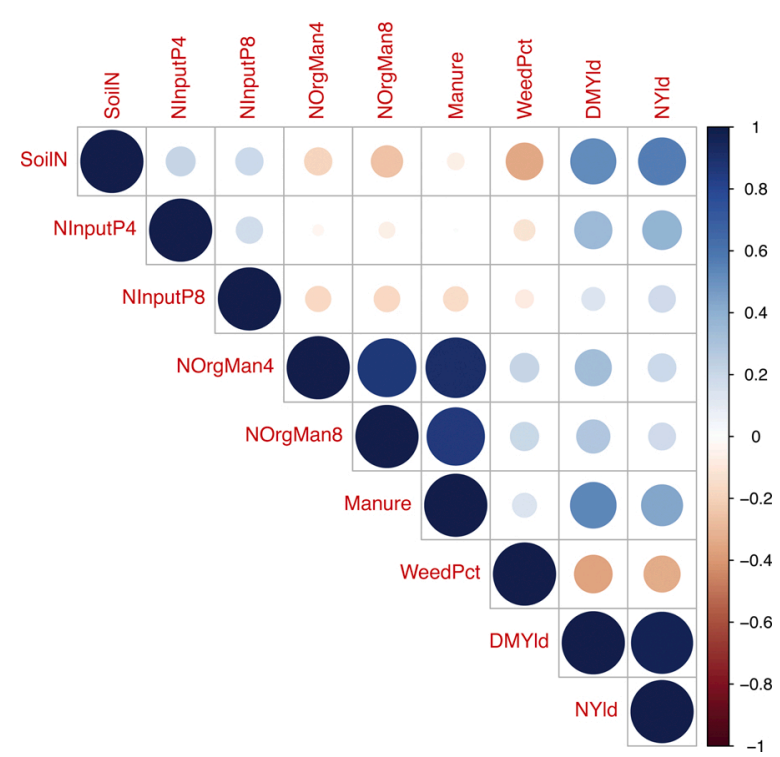

Fig. 1. Correlation between variables for winter wheat including data from all three sites for the third cycle of the experiment.



Fig. 2. Correlation between variables for spring barley including data from all three sites for the third cycle of the experiment.

Table 3

Means and standard deviations (sd) across all cycles for crop yield (DM) and weed infestation for winter wheat and spring barley for the three experimental sites.

\begin{tabular}{|c|c|c|c|c|c|c|}
\hline & \multicolumn{2}{|c|}{ Jyndevad } & \multicolumn{2}{|c|}{ Foulum } & \multicolumn{2}{|c|}{ Flakkebjerg } \\
\hline & Mean & sd & Mean & sd & Mean & sd \\
\hline \multicolumn{7}{|l|}{ Winter wheat } \\
\hline DM yield $\left(\mathrm{kg} \mathrm{ha}^{-1}\right)$ & 2046 & 1151 & 4381 & 1417 & 3337 & 1015 \\
\hline $\mathrm{N}$ yield $\left(\mathrm{kg} \mathrm{ha}^{-1}\right)$ & 29 & 13 & 71 & 26 & 52 & 20 \\
\hline Weed biomass (\% of DM) & 14 & 13 & 5 & 4 & 11 & 8 \\
\hline \multicolumn{7}{|l|}{ Spring barley } \\
\hline DM yield $\left(\mathrm{kg} \mathrm{ha}^{-1}\right)$ & 3940 & 1046 & 4505 & 763 & 3124 & 595 \\
\hline $\mathrm{N}$ yield $\left(\mathrm{kg} \mathrm{ha}^{-1}\right)$ & 56 & 18 & 73 & 16 & 49 & 11 \\
\hline Weed biomass ( $\%$ of DM) & 4 & 4 & 2 & 2 & 6 & 4 \\
\hline
\end{tabular}

barley were recorded at Flakkebjerg, where also the highest proportion of weed biomass was recorded (Table 3).

\subsection{Effect of crop management on winter cereal grain yield}

The yield effect of manure $\mathrm{N}$ application was assessed in terms of the effect of mineral $\mathrm{N}$ (ammonium) in the manure, and this effect was greatest at Foulum and smallest at Flakkebjerg (Table 4). The statistical analysis of yield of winter cereals (winter wheat, winter rye and winter triticale) distinguished between grass-clover as pre-crop and having grass-clover in the rotation, since both situations were present in the experiment, although during different cycles of the experiment (Table 1), and there was also a rotation without grass-clover in the system. Grass-clover as a pre-crop was more important for winter cereal yield than grass-clover or cover crops in the rotation, with the highest coefficient for Jyndevad (Table 4). The effect of grass-clover in the rotation was not significant for Jyndevad, and the effect of a cover crop in the rotation was not significant for any of the sites. For all sites, weeds significantly reduced both the DM and N yield of winter wheat, and the impact of the weed biomass was greatest at Foulum.

\subsection{Effect of crop management on spring barley grain yield}

The effect of manure $\mathrm{N}$ application on yield of spring barley was greatest for Jyndevad and smallest for Foulum (Table 5). Cover crops in the rotation stimulated greater dry matter yield at all sites and higher $\mathrm{N}$ 
Table 4

Mixed-effect model estimates of factors affecting dry matter (DM) and $\mathrm{N}$ grain yield of winter cereals per location using data from all cycles.

\begin{tabular}{|c|c|c|c|c|c|c|}
\hline & \multicolumn{3}{|c|}{ DM yield (kg DM ha $\left.{ }^{-1}\right)$} & \multicolumn{3}{|c|}{$\mathrm{N}$ yield $\left(\mathrm{kg} \mathrm{N} \mathrm{ha}^{-1}\right)$} \\
\hline & Jyndevad & Foulum & Flakkebjerg & Jyndevad & Foulum & Flakkebjerg \\
\hline Manure $\mathrm{N}\left(\mathrm{kg} \mathrm{NH}_{4}-\mathrm{N} \mathrm{ha}^{-1}\right)$ & $20.4 * * *$ & $27.9 * * *$ & $17.2 * * *$ & $0.25 * * *$ & $0.45 * * *$ & $0.29 * * *$ \\
\hline Grass-clover as a pre-crop & $1055 * * *$ & $549 * * *$ & $849 * * *$ & $19.7 * * *$ & $9.5 * *$ & $16.9 * * *$ \\
\hline Grass-clover in rotation & 189 & $598 * * *$ & $719 * * *$ & 1.9 & $14.2 * * *$ & $13.5 * * *$ \\
\hline Cover crop in rotation & -10 & 77 & 117 & -0.3 & 1.0 & 2.0 \\
\hline Weed biomass (\%) & $-23 * * *$ & $-53 * * *$ & $-42 *$ & $-0.33 * * *$ & $-0.80 * * *$ & $-0.73 * *$ \\
\hline $\mathrm{R}^{2}$ & 0.85 & 0.84 & 0.73 & 0.88 & 0.85 & 0.74 \\
\hline RMSE & 348 & 447 & 585 & 5.0 & 8.4 & 10.8 \\
\hline
\end{tabular}

Significance: ${ }^{*} \mathrm{P}<0.05 ; * * \mathrm{P}<0.01 ; * * * \mathrm{P}<0.001$

Table 5

Mixed-effect model estimates of factors affecting dry matter (DM) and N grain yield of spring barley per location using data from all cycles.

\begin{tabular}{|c|c|c|c|c|c|c|}
\hline & \multicolumn{3}{|c|}{ DM yield (kg DM ha ${ }^{-1}$ ) } & \multicolumn{3}{|c|}{$\mathrm{N}$ yield $\left(\mathrm{kg} \mathrm{N} \mathrm{ha}^{-1}\right)$} \\
\hline & Jyndevad & Foulum & Flakkebjerg & Jyndevad & Foulum & Flakkebjerg \\
\hline Manure $\mathrm{N}\left(\mathrm{kg} \mathrm{NH}_{4}-\mathrm{N} \mathrm{ha}^{-1}\right)$ & $28.0 * * *$ & $17.7 * * *$ & $19.7 * * *$ & $0.39 * * *$ & $0.32 * * *$ & $0.35 * * *$ \\
\hline Grass-clover in rotation & 3 & $355 * * *$ & $246 * *$ & 0.1 & $5.1 * *$ & $3.1 *$ \\
\hline Cover crop in rotation & $638 * * *$ & $714 * * *$ & $408 * * *$ & $11.8 * * *$ & $16.4 * * *$ & $8.1 * * *$ \\
\hline Weed biomass (\%) & $-39 * * *$ & $-87 * * *$ & $-32 * *$ & $-0.58 * * *$ & $-1.45 * * *$ & -0.38 \\
\hline $\mathrm{R}^{2}$ & 0.77 & 0.73 & 0.69 & 0.73 & 0.73 & 0.70 \\
\hline RMSE & 549 & 477 & 394 & 9.0 & 8.8 & 7.3 \\
\hline
\end{tabular}

Significance: * $\mathrm{P}<0.05 ; * * \mathrm{P}<0.01 ; * * * \mathrm{P}<0.001$.

yield for Foulum and Jyndevad. For all sites, the occurrence of grassclover in the rotation had a positive effect on both yields, although not significant for DM yield at Jyndevad. At all site, weeds significantly reduced the DM yield as well as the $\mathrm{N}$ yield. For spring barley the impact of the weeds was greatest at Foulum for both DM and $\mathrm{N}$ yields (Table 5).

\subsection{Cereal yield affected by $N$ supply and weeds}

Mean and standard deviation of $\mathrm{N}$ yield from various variables for winter wheat and spring barley for the third cycle are shown in Table 6 . The measured $\mathrm{N}$ yield showed a large variation with $4-124 \mathrm{~kg} \mathrm{~N}^{-1}$ for winter wheat and 23-105 $\mathrm{kg} \mathrm{N}^{-1}$ for spring barley. The mean $\mathrm{N}$ yield was greater in spring barley $\left(60.0 \mathrm{~kg} \mathrm{~N} \mathrm{ha}^{-1}\right)$ than in winter wheat $(50.4$ $\mathrm{kg} \mathrm{N} \mathrm{ha}^{-1}$ ) (Table 6). The mean percentage of weed cover under spring barley was smaller than the percentage of weed cover under winter wheat, $3.7 \%$ and $10.0 \%$ respectively. In particular, winter wheat at Jyndevad in 2007 was heavily infested by weeds with weed biomasses composing $59 \%$ of total plant biomass

The combined effects of soil $\mathrm{N}$, mineral $\mathrm{N}$ in manure and weed

Table 6

Means and standard deviations for various variables in the regression analyses for winter wheat and spring barley yield during the third cycle (2006-2009) of the experiment.

\begin{tabular}{|c|c|c|c|c|}
\hline & \multicolumn{2}{|c|}{ Winter wheat } & \multicolumn{2}{|c|}{ Spring barley } \\
\hline & mean & sd & mean & sd \\
\hline Dry matter yield $\left(\mathrm{kg} \mathrm{ha}^{-1}\right)$ & 3255 & 1529 & 3856 & 992 \\
\hline Grain $N$ yield $\left(\mathrm{kg} \mathrm{ha}^{-1}\right)$ & 50 & 27 & 60 & 18 \\
\hline Soil $\mathrm{N}$ in $0-25 \mathrm{~cm}\left(\mathrm{~kg} \mathrm{ha}^{-1}\right)$ & 4733 & 1341 & 4733 & 1341 \\
\hline $\begin{array}{l}\mathrm{N} \text { input from crop residues (1-4 years) }\left(\mathrm{kg} \mathrm{ha}^{-1}\right. \\
\left.\mathrm{yr}^{-1}\right)\end{array}$ & 90.5 & 33.5 & 88.1 & 36.1 \\
\hline $\begin{array}{l}\mathrm{N} \text { input from crop residues (5-8 years) }\left(\mathrm{kg} \mathrm{ha}^{-1}\right. \\
\left.\mathrm{yr}^{-1}\right)\end{array}$ & 96.7 & 37.0 & 96.2 & 32.4 \\
\hline $\begin{array}{l}\text { Organic } \mathrm{N} \text { input in manure (1-4 years) }\left(\mathrm{kg} \mathrm{ha}^{-1}\right. \\
\left.\mathrm{yr}^{-1}\right)\end{array}$ & 12.2 & 9.3 & 14.6 & 11.0 \\
\hline $\begin{array}{l}\text { Organic } \mathrm{N} \text { input in manure (5-8 years) }\left(\mathrm{kg} \mathrm{ha}^{-1}\right. \\
\left.\mathrm{yr}^{-1}\right)\end{array}$ & 9.6 & 8.2 & 9.6 & 8.1 \\
\hline $\mathrm{N}$ in cover crops prior to crop $\left(\mathrm{kg} \mathrm{ha}^{-1}\right)$ & - & - & 52.3 & 55.2 \\
\hline $\begin{array}{l}\text { Ammonium- } \mathrm{N} \text { input from manure in current } \\
\text { year }\left(\mathrm{kg} \mathrm{ha}^{-1}\right)\end{array}$ & 55.3 & 39.1 & 30.7 & 22.1 \\
\hline Weed biomass (\% of DM) & 10.0 & 9.7 & 3.7 & 3.7 \\
\hline
\end{tabular}

pressure on DM and $\mathrm{N}$ grain yields are shown in Tables 7 and S1, respectively. In general, most tested variables showed significant effects on both $\mathrm{N}$ and DM grain yield. The effect of topsoil total $\mathrm{N}$ content on grain $\mathrm{N}$ yield corresponded to $0.3-0.4 \%$ of topsoil total- $\mathrm{N}$ being harvested in grain yield. The effects of manure $\mathrm{N}$ application varied between locations and crops, in particular for Jyndevad which had the lowest use efficiency of manure $\mathrm{N}$ in winter wheat and the highest for spring barley. The effect of cover crop $\mathrm{N}$ incorporated prior to the main crop could only be analysed for spring barley since no cover crop was directly grown prior to winter wheat. The $\mathrm{N}$ added to the system by the cover crops had a significant positive effect on the $\mathrm{N}$ yield of spring barley. The $\mathrm{N}$ inputs from residues of previous crops had a significant positive effect for both crops, where the most recently incorporated $\mathrm{N}$ (years 1-4) showed a greater effect on winter wheat compared to $\mathrm{N}$ added in years 5-8. For spring barley this effect is opposite, the plant residues of the crop cycle 5-8 years prior had a greater effect on $\mathrm{N}$ yield of spring barley compared to $\mathrm{N}$ in crop residues added during years 1-4. This lacking effect of $\mathrm{N}$ in crop residues in the recent crop rotation cycle

Table 7

Parameter estimates for regression models on grain $\mathrm{N}$ yields $\left(\mathrm{kg} \mathrm{N} \mathrm{ha}^{-1}\right)$ of cereals of soil $\mathrm{N}$, organic $\mathrm{N}$ from crop residues for 1-4 and 5-8 years prior and weed biomass for the third cycle of the experiment. $\mathrm{N}$ Rate is the mineral $\mathrm{N}$ input from manure in the current year. The values in brackets show the standard error of the parameter estimates.

\begin{tabular}{|c|c|c|}
\hline Variable & Winter wheat & Spring barley \\
\hline Soil total $\mathrm{N}$ in $0-25 \mathrm{~cm}\left(\mathrm{~kg} \mathrm{~N} \mathrm{ha}^{-1}\right)$ & $\begin{array}{l}0.0028(0.0009) \\
* * *\end{array}$ & $\begin{array}{l}0.0038(0.0007) \\
* * *\end{array}$ \\
\hline $\begin{array}{l}\mathrm{N} \text { from crop residues (1-4 years) (kg N } \\
\left.\text { ha }^{-1} \mathrm{yr}^{-1}\right)\end{array}$ & $0.175(0.040) * * *$ & $0.058(0.036)$ \\
\hline $\begin{array}{l}\mathrm{N} \text { from crop residues (5-8 years) (kg N } \\
\left.\text { ha }^{-1} \mathrm{yr}^{-1}\right)\end{array}$ & $0.086(0.039) * *$ & $0.153(0.035) * * *$ \\
\hline $\mathrm{N}$ in cover crops prior to crop $\left(\mathrm{kg} \mathrm{N} \mathrm{ha}^{-1}\right)$ & & $0.182(0.020) * * *$ \\
\hline $\mathrm{N}$ Rate $\times$ Jyndevad $\left(\mathrm{kg} \mathrm{NH}_{4}^{+}-\mathrm{N} \mathrm{ha}^{-1}\right)$ & $0.144(0.040) * * *$ & $0.573(0.045) * * *$ \\
\hline $\mathrm{N}$ Rate $\times$ Foulum $\left(\mathrm{kg} \mathrm{NH}_{4}^{+}-\mathrm{N} \mathrm{ha}^{-1}\right)$ & $0.515(0.048) * * *$ & $0.474(0.061) * * *$ \\
\hline $\mathrm{N}$ Rate $\times$ Flakkebjerg $\left(\mathrm{kg} \mathrm{NH}_{4}^{+}-\mathrm{N} \mathrm{ha}^{-1}\right)$ & $0.384(0.049) * * *$ & $0.413(0.060) * * *$ \\
\hline Weed biomass (\%) & $\begin{array}{l}-0.538(0.137) \\
* * *\end{array}$ & $\begin{array}{l}-0.965(0.270) \\
* * *\end{array}$ \\
\hline $\mathrm{R}^{2}$ & 0.936 & 0.975 \\
\hline RMSE & 14.0 & 9.7 \\
\hline
\end{tabular}

Significance: ${ }^{* * *} \mathrm{P}<0.001 ;{ }^{*} \mathrm{P}<0.01$. 
for spring barley is likely an artefact of the statistical analysis since the effects of the $\mathrm{N}$ inputs from the cover crop directly prior to the spring barley exceeds the average $\mathrm{N}$ input in crop residues during the period 14 years prior. Also, the $\mathrm{N}$ inputs in cover crops and the $\mathrm{N}$ input in crop residues are highly correlated (Fig. 2). In both crops, the percentage of weed biomass had a significant negative effect on crop $\mathrm{N}$ yield (Table 7 ).

Tables $\mathrm{S} 2$ and 8 show the DM and $\mathrm{N}$ yield effect on winter wheat and spring barley of combining $\mathrm{N}$ in crop residues and organic $\mathrm{N}$ in applied manure for the legacy effect of $\mathrm{N}$ inputs for 1-4 and 5-8 years prior to the crops. The results are very similar to those obtained using only crop residue $\mathrm{N}$ for the legacy effects (Tables 7 and S1). However, the effect of manure application to the winter wheat crop at Jyndevad was insignificant in the new analysis that included the legacy effect of organic $\mathrm{N}$ in manure (Table 8).

\section{Discussion}

\subsection{Yield effects of crop management}

The effect of $\mathrm{N}$ added from a cover crop prior to spring barley has a positive effect on the DM and $\mathrm{N}$ yield (Table 5 and supplementary Table S1). This effect is based on the incorporation of the aboveground biomass, since no data on belowground biomass was available; however, belowground biomass can account for more than $30-40 \%$ of total $\mathrm{N}$ in cover crops (De Notaris et al., 2020; Li et al., 2015). The incorporation and subsequent decomposition of the above- and belowground biomass of the cover crops contribute to the soil organic $\mathrm{N}$ pool, which is available for subsequent crops and thereby contributing positively to crop growth and yield (Nevins et al., 2020). The effect of a cover crop in the rotation did not show significant effects on winter wheat yield when analysing data from the entire duration of the experiment (Table 4). However, cover crops are one of the main contributors of $\mathrm{N}$ in crop residues that was found to have long-term legacy effects on winter wheat yield (Table 7). For spring barley, the use of cover crops enhanced crop $\mathrm{DM}$ and $\mathrm{N}$ yield, although it was not possible to differentiate short-term versus long-term effects (Table 5). This indicates that legume-based cover crops are very important for both short-term effects on spring cereals and for the long-term soil $\mathrm{N}$ fertility that increases the $\mathrm{N}$ availability, which is as previously indicated one of the main limiting effects on yield in organic arable farming (Knapp and van der Heijden, 2018; Olesen et al., 2009, 2007; Shah et al., 2017). These findings support our

\section{Table 8}

Parameter estimates for regression models on grain $\mathrm{N}$ yields $\left(\mathrm{kg} \mathrm{N} \mathrm{ha}^{-1}\right)$ in cereals of soil $\mathrm{N}$, organic $\mathrm{N}$ from both crop residues and manure for 1-4 and 5-8 years prior and weed biomass for the third cycle of the experiment. $\mathrm{N}$ Rate is the mineral $\mathrm{N}$ input from manure in the current year. The values in brackets show the standard error of the parameter estimates.

\begin{tabular}{|c|c|c|}
\hline Variable & Winter wheat & Spring barley \\
\hline Soil total $\mathrm{N}$ in $0-25 \mathrm{~cm}\left(\mathrm{~kg} \mathrm{~N} \mathrm{ha}^{-1}\right)$ & $\begin{array}{l}0.0030(0.0009) \\
* *\end{array}$ & $0.0038(0.0007)$ \\
\hline $\begin{array}{l}\mathrm{N} \text { in crop residues and manure (1-4 years) } \\
\left(\mathrm{kg} \mathrm{N} \mathrm{ha}^{-1} \mathrm{yr}^{-1}\right)\end{array}$ & $\begin{array}{l}0.161(0.041) \\
* * *\end{array}$ & $0.054(0.035)$ \\
\hline $\begin{array}{l}\mathrm{N} \text { in crop residues and manure (5-8 years) } \\
\left(\mathrm{kg} \mathrm{N} \mathrm{ha-1}^{-1} \mathrm{yr}^{-1}\right)\end{array}$ & $0.082(0.039) *$ & $\underset{* * *}{0.155}(0.034)$ \\
\hline $\mathrm{N}$ in cover crops prior to crop $\left(\mathrm{kg} \mathrm{N} \mathrm{ha}^{-1}\right)$ & & $\begin{array}{l}0.182(0.020) \\
* * *\end{array}$ \\
\hline $\mathrm{N}$ Rate $\times$ Jyndevad $\left(\mathrm{kg} \mathrm{NH}_{4}^{+}-\mathrm{N} \mathrm{ha}^{-1}\right)$ & $0.087(0.046)$ & $\begin{array}{l}0.478(0.050) \\
* * *\end{array}$ \\
\hline N Rate $\times$ Foulum $\left(\mathrm{kg} \mathrm{NH}_{4}^{+}-\mathrm{N} \mathrm{ha}^{-1}\right)$ & $\begin{array}{l}0.471(0.049) \\
* * *\end{array}$ & $\begin{array}{l}0.410(0.062) \\
* * *\end{array}$ \\
\hline N Rate $\times$ Flakkebjerg $\left(\mathrm{kg} \mathrm{NH}_{4}^{+}-\mathrm{N} \mathrm{ha}^{-1}\right)$ & $\begin{array}{l}0.342(0.049) \\
* * *\end{array}$ & $\begin{array}{l}0.357(0.060) \\
* * *\end{array}$ \\
\hline Weed biomass (\%) & $\begin{array}{l}-0.537(0.139) \\
* * *\end{array}$ & $\begin{array}{l}-0.995(0.268) \\
* * *\end{array}$ \\
\hline $\mathrm{R}^{2}$ & 0.934 & 0.975 \\
\hline RMSE & 14.3 & 9.6 \\
\hline
\end{tabular}

Significance: $* * * \mathrm{P}<0.001 ; * * \mathrm{P}<0.01 ; * \mathrm{P}<0.05$. hypothesis that the presence of a cover crop increases the yield of cereals through enhanced crop N supply.

Grass-clover as a pre-crop and/or in the rotation has a significant positive effect on winter wheat yield for all sites, apart from Jyndevad where the effect of grass-clover in the rotation was not significant (Table 4). This lack of effect at Jyndevad can be attributed to the study design since in the first two crop cycles winter wheat was directly grown after the grass-clover. This practice caused high leaching losses in the autumn and winter after incorporation of grass-clover on the coarse sandy soil with high precipitation and limited the residual effect (Askegaard et al. 2011). For spring barley, a grass-clover in the rotation has a positive effect on DM and $\mathrm{N}$ yield at Flakkebjerg and Foulum, but not at Jyndevad (Table 5). The effect of grass-clover in contrast to mineral $\mathrm{N}$ in manure has not only a short-term, but also a long-term effect (Table 4 and 5), because the incorporation of the grass-clover biomass increases soil organic matter and thus adds to crop $\mathrm{N}$ supply through mineralisation of soil organic N (Olesen et al., 2007; Wivstad et al., 2008).

\subsection{Effects of short-term $N$ management versus long-term effects}

We found a significant effect of topsoil total $\mathrm{N}$ on grain $\mathrm{N}$ yield of both cereal crops (Table 7). This shows the importance of not only short and medium-term inputs of organic $\mathrm{N}$ for sustaining crop $\mathrm{N}$ supply, but also of the long-term soil $\mathrm{N}$ stock. The expected mineralization of the soil organic $\mathrm{N}$ pool is around $1.2 \%$ per year, based on long-term bare soil experiments in Denmark (Christensen and Olesen, 1998). The estimated effects of topsoil $\mathrm{N}$ on grain $\mathrm{N}$ yield of 0.0030 and 0.0038 correspond to 28 to $30 \%$ of the soil $\mathrm{N}$ mineralisation being recovered in the grain, which is lower than the effect of mineral $\mathrm{N}$ applied in manure (Table 7), because some of the soil $\mathrm{N}$ is mineralised outside of the period for crop $\mathrm{N}$ uptake. For both cereal crops in the third cycle, there is a positive effect on $\mathrm{DM}$ and $\mathrm{N}$ yield of $\mathrm{N}$ in previously incorporated $\mathrm{N}$ in crop residues in the crop rotation applied both 1-4 and 5-8 years prior. For winter wheat the effect is highest for the recent (1-4 year) $\mathrm{N}$ input, while for spring barley the effect of older $\mathrm{N}$ from crop residue (5-8 year) is higher. These effects may be affected by the sequence of crops and cover crops for the two species. However, in the third cycle, both cereal crops were grown after non-legume crops. Nevertheless, spring barley always succeeds a cover crop in the + CC treatments, which may well have confounded the effects of incorporated cover crops with the effect of $\mathrm{N}$ inputs in crop residues during the previous cycle. The results show that the long-term legacy effects of residue $\mathrm{N}$ inputs (5-8 years) may be about half those of the recent cycle (1-4 years). Such effects are clearly important and align well with simulated effects of soil fertility building in organic arable cropping systems (Autret et al., 2020; Doltra et al., 2019).

The effect of manure application depends on the applied rates. In the third cycle, manure was applied at rates that corresponded to about 40 and $70 \mathrm{~kg}$ ammonium-N ha ${ }^{-1}$ for spring barley and winter wheat, respectively. This corresponds to grain $\mathrm{N}$ yield effects of about 15 and 20 $\mathrm{kg} \mathrm{N} \mathrm{ha}{ }^{-1}$ for spring barley and winter wheat, respectively (Table 7), which are only slightly greater than the $\mathrm{N}$ fertility effects of grass-clover and cover crops in the rotations (Tables 4 and 5). However, there appears to be little long-term effect of manure applications, even when organic manure $\mathrm{N}$ is added to $\mathrm{N}$ in crop residues (Table 8). This low effect may be related to the generally low rates of manure used (Shah et al. 2018) combined with the slow release of organic manure $\mathrm{N}$ (Sørensen et al., 2017).

\subsection{Site-specific differences}

For all sites, grass-clover showed considerable yield benefits for winter cereals as a pre-crop, whereas the effect of grass-clover in the rotation was only present for Foulum and Flakkebjerg, but not for Jyndevad (Tables 4 and 5 and (Shah et al., 2017)). This lack of effect at Jyndevad may be partly due to the experimental design, where both 
rotations (O1 and $\mathrm{O} 2)$ during the first two cycles included grass-clover, thus not allowing effects of grass-clover in the rotation to be estimated. The site at Jyndevad has a coarse sandy soil, where the low soil water retention and the shallow rooting leads to a higher $\mathrm{N}$ leaching rate compared with Foulum and Flakkebjerg (Pandey et al., 2018). This also results in a lower amount of soil $\mathrm{N}$ available for crops at Jyndevad compared to the other two sites, and hence lower yields for winter wheat. This suggests that the fertility building of soil $\mathrm{N}$ is lower in sandy soils and therefore the effects on long-term soil fertility are lower.

\subsection{Weed pressure effect on crop yield}

Weeds reduce DM and $\mathrm{N}$ yield for both winter wheat and spring barley, where Foulum has the highest grain $\mathrm{N}$ yields and also the greatest negative effects of weed pressure on both crops. In our study, the weed pressure indicator used includes both annual and perennial weed species and is only based on the aboveground biomass. Our results show that at the average weed pressure, grain $\mathrm{N}$ yield is reduced by 5.4 and $3.6 \mathrm{~kg} \mathrm{~N} \mathrm{ha}^{-1}$ in winter wheat and spring barley, respectively. These effects are similar to some of the effects of $\mathrm{N}$ fertility building measures and illustrate the importance of aligning fertility building with weed control measures (Melander et al., 2016). Weeds can be controlled by growing more competitive varieties, sowing the crop at a higher density (Weiner et al., 2001), applying physical weeding and/or growing cover crops (Knapp and van der Heijden, 2018); however, previous studies have shown that both the crop and the weeds benefit from the applied manure (Rasmussen et al., 2006). A cover crop in autumn can make it more difficult for weeds to establish, since a well-developed cover crop canopy reduces the light available for weeds to germinate and grow and a cover crop also reduces soil available $\mathrm{N}$, thus competing with $\mathrm{N}$ supply for the weeds. However, perennial weeds in particular can benefit from for the lower possibilities for mechanical weed control in a system with cover crops (Melander et al., 2013).

Weed problems have long been a major challenge for organic growers and new methods and strategies are required to confront the problems. Weed harrowing used to be the principal method for the management of annual weeds in organic cereals and pulses. However, inter-row hoeing at increased crop row spacing has gained increased popularity among growers thanks to new guidance systems for automatic steering (Jabran et al., 2017). Weed control efficacies are better and more stable than with weed harrowing alone, especially against tall-growing species with tap-roots (Melander et al., 2018). Weed harrowing before crop emergence and sometimes post-emergence inter-row hoeing can improve the overall weeding efficacy, but hoeing is the backbone of the strategy. Perennial weeds are only partly controlled by inter-row hoeing and other measures are needed for managing this widespread problem in organic arable crops. Recent research has demonstrated the advantage of having whole-year green manure crops suitable for mowing in the crop rotation in order to manage Cirsium arvense and Sonchus arvensis (Melander et al., 2016). Green manure crops can also reduce the seed bank of annual weeds substantially (Melander et al., 2020). Cultivation campaigns between crops (usually conducted in late summer and autumn) are required for effective management of other perennial weed species, such as Elytrigia repens and Tussilago farfara (Melander et al., 2012; Rasmussen et al., 2014).

\subsection{Perspectives}

Our study shows the importance of long-term perspectives on the management of organic arable cropping systems, where it is crucial to reduce the weed pressure and maintain or build-up the soil $\mathrm{N}$ fertility. This study shows that the crop residues, either from cover crops or grassclover green manure, are important for enhancing yields of both winter wheat and spring barley. Our results indicate that the legacy effects of soil fertility building last beyond individual crop rotation cycles, and we were able to trace such effects 5-8 year back in time. Such legacy effects are experimentally difficult to demonstrate, and we suggest that further studies are needed to qualify our estimates since these are of paramount importance for qualifying the economic viability of soil fertility management, not only in organic farming but also in the wider conventional agriculture.

\section{Conclusions}

The study used data on crop yields of spring barley and winter cereals from a long-term experiment at three sites in Denmark with treatments varying in soil fertility management. The cereal grain $\mathrm{N}$ yields were influenced by topsoil total- $\mathrm{N}$ content, short-term $\mathrm{N}$ inputs in manure and cover crops and long-term organic $\mathrm{N}$ inputs, primarily from crop residues such as grass-clover green manure crops, cover crops and residues of grain legumes. The effect of crop residue $\mathrm{N}$ input varied with the age of the incorporated material, for winter wheat the effect of $\mathrm{N}$ input in crop residues during the previous 1-4 years was about twice that of 5-8 years ago, while for spring barley the opposite effect is seen. However, for spring barley, the short-term effect of crop residues (1-4 years) included the effect of cover crops immediately prior to the barley and the other residue inputs of this period. This cumulated effect of residue $\mathrm{N}$ input 1-4 years prior was also for spring barley greater than that of 5-8 years prior, although these effects on grain $\mathrm{N}$ were greater for spring barley than for winter wheat. In addition to the effects of $\mathrm{N}$ input, weed pressure was found to significantly affect grain DM and $\mathrm{N}$ yield at all three sites. These effects depend on the soil conditions at the site, and the soil $\mathrm{N}$ fertility building is lower for the sandy compared to loamy soils, since the water holding capacity is lower and therefore more nitrate is leached and lost from the soil system. This study highlights the importance of managing soil $\mathrm{N}$ fertility and weed pressure in arable organic farming, and that such effects are not constrained to short-term effects, and legacy effects spanning up to a decade impact DM and $\mathrm{N}$ yield.

\section{Declaration of Competing Interest}

The authors declare that they have no known competing financial interests or personal relationships that could have appeared to influence the work reported in this paper.

\section{CRediT authorship contribution statement}

Johannes Wilhelmus Maria Pullens: Methodology, Software, Validation, Writing - original draft, Formal analysis, Investigation. Peter Sørensen: Validation, Resources, Writing - review \& editing. Bo Melander: Validation, Resources, Writing - review \& editing. Jørgen Eivind Olesen: Conceptualization, Data curation, Supervision, Writing - review \& editing.

\section{Declaration of Competing Interest}

The authors report no declarations of interest.

\section{Acknowledgements}

The study was financially supported by the HighCrop and NUTHY projects funded by the Green Growth and Development Programme (GUDP) of the DanishMinistry of Environment and Food and coordinated under ICROFS. Additional financial support was provided by the FertilCrop projectunder the EU FP7 ERA-Net CORE Organic Plus, cofunded by the European Commission and the Danish Ministry of Environment and Food.

\section{Appendix A. Supplementary data}

Supplementary material related to this article can be found, in the 
online version, at doi:https://doi.org/10.1016/j.eja.2020.126169.

\section{References}

Askegaard, M., Olesen, J.E., Rasmussen, I.A., Kristensen, K., 2011. Nitrate leaching from organic arable crop rotations is mostly determined by autumn field management. Agric. Ecosyst. Environ. 142, 149-160. https://doi.org/10.1016/J. AGEE. 2011.04.014.

Autret, B., Mary, B., Strullu, L., Chlebowski, F., Mäder, P., Mayer, J., Olesen, J.E., Beaudoin, N., 2020. Long-term modelling of crop yield, nitrogen losses and GHG balance in organic cropping systems. Sci. Total Environ. 710, 134597. https://doi. org/10.1016/j.scitotenv.2019.134597.

Bates, D., Mächler, M., Bolker, B., Walker, S., 2015. Fitting Linear Mixed-Effects Models Using lme4. J. Stat. Softw. 67, 1-48. https://doi.org/10.18637/jss.v067.i01.

Berry, P.M., Sylvester-Bradley, R., Philipps, L., Hatch, D.J., Cuttle, S.P., Rayns, F.W., Gosling, P., 2006. Is the productivity of organic farms restricted by the supply of available nitrogen? Soil Use Manag. 18, 248-255. https://doi.org/10.1111/j.14752743.2002.tb00266.x.

Brozyna, M.A., Petersen, S.O., Chirinda, N., Olesen, J.E., 2013. Effects of grass-clover management and cover crops on nitrogen cycling and nitrous oxide emissions in a stockless organic crop rotation. Agric. Ecosyst. Environ. 181, 115-126. https://doi. org/10.1016/J.AGEE.2013.09.013.

Büchmann, N.B., Josefsson, H., Cowe, I.A., 2001. Performance of European Artificial Neural Network (ANN) Calibrations for Moisture and Protein in Cereals Using the Danish Near-Infrared Transmission (NIT) Network. Cereal Chem. J. 78, 572-577. https://doi.org/10.1094/CCHEM.2001.78.5.572.

Cadillo-Benalcazar, J.J., Renner, A., Giampietro, M., 2020. A multiscale integrated analysis of the factors characterizing the sustainability of food systems in Europe. J. Environ. Manage. 271, 110944. https://doi.org/10.1016/j.jenvman.2020.110944.

Christensen, B.T., Olesen, J.E., 1998. Nitrogen mineralization potential of organomineral size separates from soils with annual straw incorporation. Eur. J. Soil Sci. 49, 25-36. https://doi.org/10.1046/j.1365-2389.1998.00130.x.

De Notaris, C., Olesen, J.E., Sørensen, P., Rasmussen, J., 2020. Input and mineralization of carbon and nitrogen in soil from legume-based cover crops. Nutr. Cycl. Agroecosystems 116, 1-18. https://doi.org/10.1007/s10705-019-10026-z.

De Notaris, C., Rasmussen, J., Sørensen, P., Olesen, J.E., 2018. Nitrogen leaching: A crop rotation perspective on the effect of $\mathrm{N}$ surplus, field management and use of catch crops. Agric. Ecosyst. Environ. 255, 1-11. https://doi.org/10.1016/j. agee.2017.12.009.

De Ponti, T., Rijk, B., Van Ittersum, M.K., 2012. The crop yield gap between organic and conventional agriculture. Agric. Syst. 108, 1-9. https://doi.org/10.1016/j. agsy.2011.12.004.

Djurhuus, J., Olesen, J.E., 2000. Characterisation of four sites in Denmark for long-term experiments on crop rotations for organic farming, in: DIAS Report. Plant Production; Nr. 33.

Doltra, J., Gallejones, P., Olesen, J.E., Hansen, S., Frøseth, R.B., Krauss, M., Stalenga, J. Jończyk, K., Martínez-Fernández, A., Pacini, G.C., 2019. Simulating soil fertility management effects on crop yield and soil nitrogen dynamics in field trials under organic farming in Europe. F. Crop. Res. 233, 1-11. https://doi.org/10.1016/J. FCR.2018.12.008.

Gabriel, D., Sait, S.M., Kunin, W.E., Benton, T.G., 2013. Food production vs. biodiversity: Comparing organic and conventional agriculture. J. Appl. Ecol. 50, 355-364. https://doi.org/10.1111/1365-2664.12035.

Godfray, H.C.J., Beddington, J.R., Crute, I.R., Haddad, L., Lawrence, D., Muir, J.F., Pretty, J., Robinson, S., Thomas, S.M., Toulmin, C., 2010. Food security: the challenge of feeding 9 billion people. Science 327, 812-818. https://doi.org/ 10.1126/science.1185383.

Hansen, B., 1989. Determination of Nitrogen as Elementary N, an Alternative to Kjeldahl. Acta Agric. Scand. 39, 113-118. https://doi.org/10.1080/00015128909438504.

ICROFS, 2019. Forsknings- og udviklingsstrategi $2019 \emptyset$ kologisk jordbrug og fødevaresystemer (Research and development strategy 2019 in organic farming and food systems). International Centre for Research in Organic Food System, Denmark.

Jabran, K., Mahmood, K., Melander, B., Bajwa, A.A., Kudsk, P., 2017. Weed Dynamics and Management in Wheat. Advances in Agronomy. Academic Press Inc, pp. 97-166. https://doi.org/10.1016/bs.agron.2017.05.002.

Knapp, S., van der Heijden, M.G.A., 2018. A global meta-analysis of yield stability in organic and conservation agriculture. Nat. Commun. 9, 3632. https://doi.org/ 10.1038/s41467-018-05956-1.

Knudsen, M.T., Meyer-Aurich, A., Olesen, J.E., Chirinda, N., Hermansen, J.E., 2014. Carbon footprints of crops from organic and conventional arable crop rotations using a life cycle assessment approach. J. Clean. Prod. 64, 609-618. https://doi.org/ 10.1016/J.JCLEPRO.2013.07.009.

Lancashire, P.D., Bleiholder, H., Van Den Boom, T., Langelüddeke, P., Stauss, R., Weber, E., Witzenberger, A., 1991. A uniform decimal code for growth stages of crops and weeds. Ann. Appl. Biol. 119, 561-601. https://doi.org/10.1111/j.17447348.1991.tb04895.x.

Li, X., Petersen, S.O., Sørensen, P., Olesen, J.E., 2015. Effects of contrasting catch crops on nitrogen availability and nitrous oxide emissions in an organic cropping system. Agric. Ecosyst. Environ. 199, 382-393. https://doi.org/10.1016/j. agee.2014.10.016

Mäder, P., Fliessbach, A., Dubois, D., Gunst, L., Fried, P., Niggli, U., 2002. Soil fertility and biodiversity in organic farming. Science 296, 1694-1697. https://doi.org/ 10.1126/science.1071148.
Melander, B., Holst, N., Rasmussen, I.A., Hansen, P.K., 2012. Direct control of perennial weeds between crops - Implications for organic farming. Crop Prot. 40, 36-42. https://doi.org/10.1016/J.CROPRO.2012.04.029.

Melander, B., Jabran, K., De Notaris, C., Znova, L., Green, O., Olesen, J.E., 2018. Interrow hoeing for weed control in organic spring cereals-Influence of inter-row spacing and nitrogen rate. Eur. J. Agron. 101, 49-56. https://doi.org/10.1016/j. eja.2018.08.005.

Melander, B., Nørremark, M., Kristensen, E.F., 2013. Combining mechanical rhizome removal and cover crops for Elytrigia repens control in organic barley systems. Weed Res. 53, 461-469. https://doi.org/10.1111/wre.12042.

Melander, B., Rasmussen, I.A., Olesen, J.E., 2020. Legacy effects of leguminous green manure crops on the weed seed bank in organic crop rotations. Agric. Ecosyst. Environ. 302, 107078. https://doi.org/10.1016/j.agee.2020.107078.

Melander, B., Rasmussen, I.A., Olesen, J.E., 2016. Incompatibility between fertility building measures and the management of perennial weeds in organic cropping systems. Agric. Ecosyst. Environ. 220, 184-192. https://doi.org/10.1016/J. AGEE. 2016.01.016.

Nevins, C.J., Lacey, C., Armstrong, S., 2020. The synchrony of cover crop decomposition, enzyme activity, and nitrogen availability in a corn agroecosystem in the Midwest United States. Soil Tillage Res. 197, 104518. https://doi.org/10.1016/j. still.2019.104518.

Olesen, J.E., Askegaard, M., Rasmussen, I.A., 2009. Winter cereal yields as affected by animal manure and green manure in organic arable farming. Eur. J. Agron. 30, 119-128. https://doi.org/10.1016/J.EJA.2008.08.002.

Olesen, J.E., Askegaard, M., Rasmussen, I.A., 2000. Crop production during the first course of an organic crop rotation trial in Denmark. Asp. Appl. Biol. 62, 187-195.

Olesen, J.E., Hansen, E.M., Askegaard, M., Rasmussen, I.A., 2007. The value of catch crops and organic manures for spring barley in organic arable farming. F. Crop. Res. 100, 168-178. https://doi.org/10.1016/J.FCR.2006.07.001.

Pandey, A., Li, F., Askegaard, M., Olesen, J.E., 2017. Biological nitrogen fixation in three long-term organic and conventional arable crop rotation experiments in Denmark. Eur. J. Agron. 90, 87-95. https://doi.org/10.1016/j.eja.2017.07.009.

Pandey, A., Li, F., Askegaard, M., Rasmussen, I.A., Olesen, J.E., 2018. Nitrogen balances in organic and conventional arable crop rotations and their relations to nitrogen yield and nitrate leaching losses. Agric. Ecosyst. Environ. 265, 350-362. https://doi. org/10.1016/j.agee.2018.05.032.

Petersen, S.O., Schjønning, P., Olesen, J.E., Christensen, S., Christensen, B.T., 2013. Sources of Nitrogen for Winter Wheat in Organic Cropping Systems. Soil Sci. Soc. Am. J. 77, 155. https://doi.org/10.2136/sssaj2012.0147.

Plantedirektoratet, 2005. Statistik over $\varnothing$ kologiske Jordbrugsbedrifter 2004. Lyngby, Denmark.

Plantedirektoratet, 1997. Vejledning og skemaer, mark og gødningsplan, gødningsregnskab, Grønne Marker 1997/1998. Lyngby, Denmark.

Ponisio, L.C., M'gonigle, L.K., Mace, K.C., Palomino, J., Valpine, P.D., Kremen, C., 2015. Diversification practices reduce organic to conventional yield gap. Proc. R. Soc. B Biol. Sci. 282 https://doi.org/10.1098/rspb.2014.1396.

R Development Core Team, 2018. R Foundation for Statistical Computing. A language and environment for statistical computing.

Rasmussen, I.A., Askegaard, M., Olesen, J.E., Kristensen, K., 2006. Effects on weeds of management in newly converted organic crop rotations in Denmark. Agric. Ecosyst. Environ. 113, 184-195. https://doi.org/10.1016/J.AGEE.2005.09.007.

Rasmussen, I.A., Melander, B., Askegaard, M., Kristensen, K., Olesen, J.E., 2014. Elytrigia repens population dynamics under different management schemes in organic cropping systems on coarse sand. Eur. J. Agron. 58, 18-27. https://doi.org/10.1016/ J.EJA.2014.04.003.

Rasmussen, K., Rasmussen, J., 2000. Barley seed vigour and mechanical weed control. Weed Res. 40, 219-230. https://doi.org/10.1046/j.1365-3180.2000.00184.x.

Schils, R., Olesen, J.E., Kersebaum, K.C., Rijk, B., Oberforster, M., Kalyada, V., Khitrykau, M., Gobin, A., Kirchev, H., Manolova, V., Manolov, I., Trnka, M., Hlavinka, P., Paluoso, T., Peltonen-Sainio, P., Jauhiainen, L., Lorgeou, J., Marrou, H., Danalatos, N., Archontoulis, S., Fodor, N., Spink, J., Roggero, P.P., Bassu, S., Pulina, A., Seehusen, T., Uhlen, A.K., Żyłowska, K., Nieróbca, A., Kozyra, J., Silva, J.V., Maçãs, B.M., Coutinho, J., Ion, V., Takáč, J., Mínguez, M.I., Eckersten, H., Levy, L., Herrera, J.M., Hiltbrunner, J., Kryvobok, O., Kryvoshein, O., Sylvester-Bradley, R., Kindred, D., Topp, C.F.E., Boogaard, H., de Groot, H., Lesschen, J.P., van Bussel, L., Wolf, J., Zijlstra, M., van Loon, M.P., van Ittersum, M. K., 2018. Cereal yield gaps across Europe. Eur. J. Agron. 101, 109-120. https://doi. org/10.1016/j.eja.2018.09.003.

Seufert, V., Ramankutty, N., Foley, J.A., 2012. Comparing the yields of organic and conventional agriculture. Nature. https://doi.org/10.1038/nature11069.

Shah, A., Askegaard, M., Rasmussen, I.A., Jimenez, E.M.C., Olesen, J.E., 2017. Productivity of organic and conventional arable cropping systems in long-term experiments in Denmark. Eur. J. Agron. 90, 12-22. https://doi.org/10.1016/j. eja.2017.07.001.

Sørensen, P., Thomsen, I.K., Schröder, J.J., 2017. Empirical model for mineralisation of manure nitrogen in soil. Soil Res. 55, 500-505. https://doi.org/10.1071/SR17018.

Springmann, M., Clark, M., Mason-D’Croz, D., Wiebe, K., Bodirsky, B.L., Lassaletta, L., de Vries, W., Vermeulen, S.J., Herrero, M., Carlson, K.M., Jonell, M., Troell, M., DeClerck, F., Gordon, L.J., Zurayk, R., Scarborough, P., Rayner, M., Loken, B., Fanzo, J., Godfray, H.C.J., Tilman, D., Rockström, J., Willett, W., 2018. Options for keeping the food system within environmental limits. Nature 562, 519-525. https:// doi.org/10.1038/s41586-018-0594-0.

Statistics Denmark, 2019. Statistics Denmark [WWW Document]. 2019-04-09. URL www.dst.dk (accessed 4.9.19). 
Weiner, J., Griepentrog, H.-W., Kristensen, L., 2001. Suppression of weeds by spring wheat Triticum aestivum increases with crop density and spatial uniformity. J. Appl. Ecol. 38, 784-790. https://doi.org/10.1046/j.1365-2664.2001.00634.x.

Willett, W., Rockström, J., Loken, B., Springmann, M., Lang, T., Vermeulen, S., Garnett, T., Tilman, D., DeClerck, F., Wood, A., Jonell, M., Clark, M., Gordon, L.J., Fanzo, J., Hawkes, C., Zurayk, R., Rivera, J.A., De Vries, W., Majele Sibanda, L., Afshin, A., Chaudhary, A., Herrero, M., Agustina, R., Branca, F., Lartey, A., Fan, S., Crona, B., Fox, E., Bignet, V., Troell, M., Lindahl, T., Singh, S., Cornell, S.E., Srinath Reddy, K., Narain, S., Nishtar, S., Murray, C.J.L., 2019. Food in the Anthropocene: the EAT-Lancet Commission on healthy diets from sustainable food systems. Lancet 393, 447-492. https://doi.org/10.1016/S0140-6736(18)31788-4.

Wivstad, M., Dahlin, A.S., Grant, C., 2008. Perspectives on nutrient management in arable farming systems. Soil Use Manag. 21, 113-121. https://doi.org/10.1111, j.1475-2743.2005.tb00115.x.

Zhao, J., De Notaris, C., Olesen, J., 2020. Autumn-based vegetation indices for estimating nitrate leaching during autumn and winter in arable cropping systems. Eur. J. Agron. 290 https://doi.org/10.1016/j.agee.2019.106786. 